\title{
Value at Risk Analysis towards Automotive Sub Sector Shares and its Components at Indonesia Stock Exchange
}

\author{
Sri Nurul Mulyanah ${ }^{1}$ \\ Student of Magister Management, MercuBuana University \\ Jakarta, Indonesia
}

\author{
Abitur Asianto ${ }^{2}$ \\ Lecturer of Postgraduate, MercuBuana University \\ Jakarta, Indonesia
}

\begin{abstract}
The purpose from this research was to analyzed those optimum model with Autoregressive Conditional Heteroscsedasticity - Generalized Autoregressive Conditional Heteroscedasticity (ARCH-GARCH) from automotive sector shares and estimated the calculation investment risk analysis the Value at Risk method approach used $95 \%$ confidence level and holding period which provides information on maximum potential loss towards stock return value. Data From these research was secondary data for time series in form of monthly Shares return value from Astra Internasional, Astra Otoparts, Goodyear Indonesia, Gajah Tunggal, Indomobil Sukses Internasional, and Prima Alloy Steel Universal. Data was obtained from www.idx.co.id, yahoo.finance.com and other sources from December 2013 to August 2019.The risk analysis tool for calculating Value at Risk with Variance-covariance type. The Conclusion from these research results Was the data was stationary which does not had normal distribution and the longer the investment
\end{abstract}

takes, the higher the loss rate. This research was expected to be useful for policy makers to consider decisions regarding investment decisions in automotive sector or related companies to develop Indonesian economy and this research was expected to broaden knowledge, views and information and could provide empirical evidence about Value At risk analysis Through ARCH-GARCH model.

Keywords: Shares Return, Automotive Sector Shares, ARCHGARCH, VaR.

\section{INTRODUCTION}

The automotive industry is one type of business which is growth rapidly in Indonesia therefore it would encourage economic growth. The automotive sector is an important for Indonesia's various industrial sectors. These following table is the total value of automotive sub-sector shares and its components in Table 1.

\begin{tabular}{lllll}
\hline No & Code & Company Name & Record Date & Shares \\
\hline 1 & ASII & PT. Astra Internasional Tbk. & 04-Apr-90 & 40.483 .553 .140 \\
\hline 2 & AUTO & PT. Astra Otoparts Tbk. & 15-Jun-98 & 4.819 .733 .000 \\
\hline 3 & GDYR & PT. Goodyear Indonesia Tbk. & 01 Des 1980 & 410.000 .000 \\
\hline 4 & GJTL & PT. Gajah Tunggal Tbk. & 08 Mei 1990 & 3.484 .800 .000 \\
\hline 5 & IMAS & PT. Indomobil Sukses Makmur Tbk. & 15-Sep-93 & 2.765 .278 .412 \\
\hline 6 & PRAS & PT. Prima Alloy Steel Universal Tbk. & 12-Jul-90 & 701.043 .478 \\
\hline
\end{tabular}

Table 1:- Automotive Sector Shares and Components

Source: www.idx.co.id accessed in July 2019

Based on those table above, the share value and listing date (IPO) on market capital was different and Also return value that generated by companies it is also fluctuative. Investors will consider the condition of the company to be good If it could provide positive signal to investors in capital market who will resulting in increase of share prices due to increasing demand for its shares in the capital market. There are three purposes why investors funds their money inmarket capital: First to earned dividends or profits which delivered by each company In the end of financial year. second ,They will get capital again, which is the profits that obtained From shareholders due to an increasing in share prices and Third earn both. The data from stock returns of various industrial sectors At Indonesian stock exchange in which there has automotive sub-sectors could be seen as its follows: 


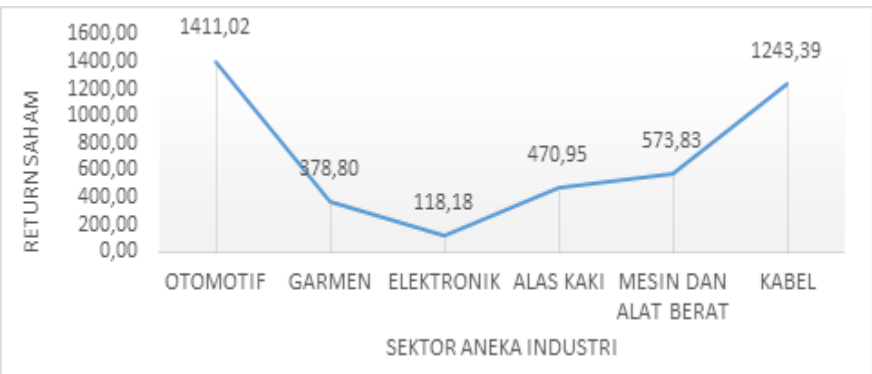

Fig. 1:- Comparison of various industriesShares Returns 20132019

Source: Data were processed by Author on December 2019

Based on Figure 1, there has interesting phenomenon which occured on various industry sector's stocks return said that the automotive sub-sector received a high retrun in 20132019, which is IDR 1411.02 compared to other subsectors. while sub-sector stock returns from garment is Rp.378.80, While on electronic sub sector stock retrun of IDR 118.18. The return of shares in footwear sub sector was IDR 470.95, return for machines and Heavy equipment Sub- sector was IDR 573.83 and the shares return of cable subsector was IDR 1243.39 .

One of the newest approaches in estimating the risk value of an investment was using the Value at Risk method.This research will analyze how measurement of the risk of loss that may be obtained on investment in automotive sector Shares and Its components by Value at Risk (VaR) analysis method through Auto regresive Conditional Heteroscedasticity (ARCH) and Generalized Autoregresive Conditional Heteroscedasticity (GARCH).Investors could measured the risk quantitatively through statistical and mathematical models which designed to obtain volatility values from single asset and stock returns which tested.

\section{LITERATURE REVIEW}

\section{A. Investments}

According to Bodie, Kane, \& Marcus (2018) defines the investment as follows: "An investment is the current commitment of money or other resources in expectation to reaping the future benefits". This means that investment is a commitment for a number of funds or other resources committed at this time with hope will get benefit in the future. Based on these definition above, it could be concluded that investment is a commitment from investors to allocate some of capital, funds, assets or other resources currently with purpose to gets a profit or return better that exceed hope in the future. Stock investment was the main topic of this research Its generally related to activity of investors in making purchases, sales and hold shares at capital market.

\section{B. Return}

Campbell, Lo, and MacKinlay (1997) gave two main reasons why should using return. First, mostly for investors, return on assets is a summary complete and concise investment opportunity. Second, the return series was easier to handlerather than price series because it hasstatistical properties which making it more interesting. According to Brigham \& Houston (2011) Return is the difference between the amount received and amount invested and dividing the amount invested. While according to Fahmi and Hadi (2009) Return is an advantage that obtained by companies, individuals and institutions as the results from their investment policies.Based on these definitions, it can be concluded that return is a rateof repayment from sale and buy the shares

\section{Value at Risk}

According to Jorion (2011), Value at Risk (VaR) in financial context is estimation from risk with certain level of confidence Regarding how much it could be lost due to portfolio over a specified time horizontally. A portfolio can be a single asset or

Combination of several security assets. The risk measure that has been defined since the year 1990s in financial theory and practice called Value at Risk (VaR). Andreas de Vries in 2000 explained that this risk measure Popularized by J.P.Morgan's Risk Metrics, a database that provides dataimportant statistic for calculating the $\mathrm{VaR}$ of derivatives. $\mathrm{VaR}$ is currently run by all financial managers as an important tool in overall risk management process. Thing could be motivated by the presence of several financial disaster events involving trading in derivative products, such as the collapse of the Barrings Bank. VaR is a measure downside risks were concentrated on low probability events occurring in Tail down distribution. The critical value at the end of period of a portfolio was determined in advance first as the worst possible end-of-period value for portfolio with a predefined confidence level of " 1 - c", for example at $99 \%$ or $95 \%$.Its assumed that the worst value will not be greater than c percent of the time. For example, the estimated of daily $\mathrm{VaR}$ value of a trading portfolio worth to1 million dollars at a 99\% confidence level. This implies that in normal market conditions, only $1 \%$ from the time, the portfolio loss will be exceed Than 1 million. VaR describes the quantile distribution of profit and loss projected over the target horizon, the general formula for estimation VaR is:

$$
\operatorname{VaR}=\left(\sigma_{t+1} \cdot \sqrt{b}\right) \cdot Z_{\alpha} \cdot W
$$

Whereas VaR is the amount of risk, b the investment period, $\mathrm{Z} \alpha$ is the critical point in table $\mathrm{Z}$ with a confidence interval of $95 \%, \mathrm{~W}$ the investment value and $\sigma \mathrm{t}+1$ is further standard deviation 


\section{Value at Risk for Single Instrument}

VaR for a single asset according to Jorion was calculated by these following equation:

$$
V a R=\alpha \times \sigma \times P
$$

When holding period was taken, these VaR formula wouldbecomes:

$$
V a R=\alpha \times \sigma \times P \times \sqrt{t}
$$

The confidence level chosen was 95\%, the estimation Value at Riskis daily of Value at Risk that shows the amount of loss faced by investors in 1 day, 5 days and 20 days. This daily VaR was presented for IDR 1.00, Suppose recorded VaR value -0.05 , it means that loss rate was $5 \%$ per IDR 1.00 .

\section{E. ARCH/GARCH}

According to Asianto, et., al. (2019), high volatility and error variance inconsistencies often occur in time series data, for example in price shares, inflation rate, makro economic indicators and others. This called data had experience the heteroscedasticity effect. The results from OLS data analysis shows that assumptions parameters were unbiased and consistent. Engle (1982) offers an Autoregressive Conditional Heteroscedasticity model (ARCH) to overcome this. Autoregressive shows that there had relationship between current data and the past. Conditionals denote variant dependence on past data information. In the $\mathrm{ARCH}$ (Engle, 1982) The conditional variance (ht) depends on the residuals from past squares. Financial risk is an unexpected fluctuation result due to movement Financial variables Analysis of variance and forecasting future volatility using ARCH-GARCH model (Jorion 2011).Here's the equation:

$$
\begin{gathered}
\sigma_{t}^{2}=\alpha_{0}+\sum_{i=1}^{p} \alpha_{i} e_{t-1}^{2}+\sum_{j=1}^{q} \lambda_{j} \sigma_{t-j}^{2} ; \text { or } \\
\sigma_{t}^{2}=\alpha_{0}+\sum_{i=1}^{p} \alpha_{i} e_{t-1}^{2}+\sum_{j=1}^{q} \lambda_{j} \sigma_{t-j}^{2}
\end{gathered}
$$

\section{F. Volatility}

Return volatility was indicated byvariance or standard deviation. Volatility used to measure statistical variations in the price of an instrument. When do forecasting, volatility was generally assumed to be constant over time, although the fact that is not, constant volatility over time is called homoscedastic, while volatility that sun constant is called heteroscedastic.

\section{G. Prior Research by ARCH-GARCH and VaRMethod}

Asiantoet.al. (2019)were analyzed the Value at Risk selling option on WTI with ARCH-GARCH method had explained that strike far out of the money (FOTM) is a low risk was $12 \%$ with return up to $11 \%$ per year. Bilir (2016) was Analyzed thoss $\mathrm{VaR}$ value towards portfolio by covariance model approach. It could be concludes that total risk can be broken down as a systematic part. Li et al. (2016) had compared between Brent and WTI with GARCH-type model in perspective short-term VaR analysis explains that Brent had the best performance for EGARCH $(1,1)$ toppled other GARCH models. Soedewi and Purqo (2015) stated that with GARCH model of volatility forecasting period Iand II of 2015 shows that LPKR shares hadvolatilityvariable was 0.00040.00137, and BMRI had volatility range from 0.0018 0.0040.Waharika, et., al.(2013) explained that GARCH method was good enough to estimate the VaR value at stock index because there had heteroscedastic volatility. VaR value on horizon 1, 10 and 22 days at $95 \%$ confidence level was indicated that the longer the investment the greater the risk for investors. Dwipa (2016) concluded that the GARCH model $(1,1)$ is the best model. Value at Risk (VaR) for investment of Rp 500,000,000 at the $95 \%$ confidence level was indicated a risk of IDR 3,622,420.50.

\section{H. Theoretical Framework}

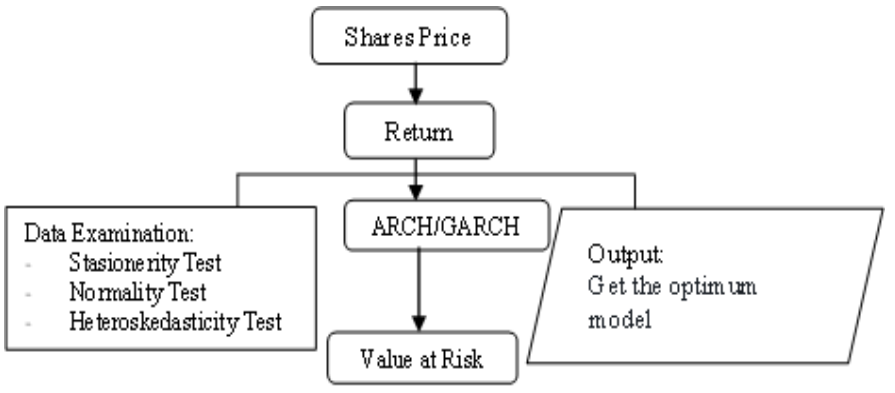

Fig. 2:- Theoretical Framework

\section{Hypothesis}

Based on background of the problem, these problem formulation, research purposed as wellas literature review that has been described above, then the proposed hypothesis in these research were as its follows:

H1: There had an optimum model for ARCH/GARCH method $\mathrm{H} 2$ : There had big risk by Value at Risk

\section{RESEARCH METHODOLOGY}

This type of research were analyzed the Value at Risk of stocks in automotive sector in Indonesia Stock Exchange with ARCH-GARCH volatility model with time series data for period of December 2013 to August 2019. The variable in this research were stock price from automotive sector with estimation by the stock return of each automotive sector share that listed on Indonesia Stock Exchange. Stock return data of each share price in automotive sector which registeredin Indonesia Stock Exchange was estimated to determine the amount of risk in share prices by Value at Risk (VaR) from estimation volatility through a volatility model of Autoregresive Conditional Heteroscesdasticity (ARCH) and Generalized Autoregresive Conditional Heteroscedasticity (GARCH).The type of sample used was purposive sampling, which is the sampling technique with certain considerations 
(Sugiyono: 2013). The Reason why the author in having purposive sampling technique was because not all samples had criteria in accordance with what the authors specify with the criteria, namely:

1) Automotive companies on IDX from 2013-2019

2) Have complete data that required in these research

3) Companies had published share price data during the 20132019 period.

This research was consists of two analyzes, namely the optimum model analysis that obtained from ARCH-GARCH calculation and Value at Risk calculation analysis of each share. These stages of data processing were stationarity test, normality test, heteroscedasticity test, ARCH / GARCH test and VaR estimation.

\section{RESULT AND DISCUSSION}

\section{A. Data Return Examination}

The return of each share price was estimated by the natural logarithm approach of share price ratio. These following is the calculation of shares return result that can be seen in the table below:

\begin{tabular}{rrrrrrr}
\hline \multicolumn{1}{l}{ Date } & \multicolumn{1}{l}{ ASII } & \multicolumn{1}{l}{ AUTO } & \multicolumn{1}{l}{ GJTL } & \multicolumn{1}{l}{ GDYR } & \multicolumn{1}{l}{ IMAS } & \multicolumn{1}{l}{ PRAS } \\
\hline $01 / 12 / 2013$ & 0 & 0 & 0 & 0 & 0 & 0 \\
\hline $01 / 01 / 2014$ & $-0,05680$ & $-0,07981$ & 0,014599 & 0 & $-0,00102$ & $-0,04421$ \\
\hline $01 / 02 / 2014$ & 0,07851 & 0,067409 & 0,035591 & $-0,02667$ & 0,065241 & 0,070874 \\
\hline $01 / 03 / 2014$ & 0,05944 & 0,103973 & $-0,0725$ & 0,026668 & $-0,0048$ & 0,015666 \\
\hline & - & - & - & - & & - \\
\hline & - & - & - & - & & - \\
\hline $01 / 05 / 2019$ & $-0,02330$ & $-0,03062$ & 0,103864 & $-0,05628$ & $-0,03993$ & $-0,04205$ \\
\hline $01 / 06 / 2019$ & 0,02102 & $-0,01036$ & 0,030334 & 0 & $-0,00743$ & $-0,01858$ \\
\hline $01 / 07 / 2019$ & $-0,06230$ & $-0,00348$ & $-0,1498$ & 0,043765 & $-0,11452$ & 0,006231 \\
\hline $01 / 08 / 2019$ & $-0,04754$ & $-0,07223$ & $-0,11541$ & 0 & $-0,25424$ & $-0,00623$ \\
\hline
\end{tabular}

Table 2:- ASII, AUTO, GJTL, GDYR, IMAS, PRAS Stock Returns

Source: yahoo.finance.com, reprocessed by excel application (2019)

\section{B. Stationarity Test}

The stationarity test used Augmented Dickey Fuller Test (ADF-Test) method towards stock return data with Eviews software application, by looking at comparison between ADF value Test statistic with critical values. A data has said to be stationary if the value of ADF Test statistic < test critical values $5 \%$ level.

\begin{tabular}{|c|c|c|c|c|}
\hline & & & t-Statistic & Prob.* \\
\hline$\frac{\text { Augmented Dickey-F }}{\text { Test critical values: }}$ & $\begin{array}{c}\text { test statistic } \\
1 \% \text { level } \\
5 \% \text { level } \\
10 \% \text { level }\end{array}$ & & $\begin{array}{l}-8.682152 \\
-3.530030 \\
-2.904848 \\
-2.589907\end{array}$ & 0.0000 \\
\hline \multicolumn{5}{|c|}{$\begin{array}{l}\text { *MacKinnon (1996) one-sided p-values. } \\
\text { Augmented Dickey-Fuller Test Equation } \\
\text { Dependent Variable: D(ASII) } \\
\text { Method: L east Squares } \\
\text { Date: 01/22/20 Time: 19:07 } \\
\text { Sample (adjusted): } 2014 \mathrm{MO} 12019 \mathrm{M} 08 \\
\text { Included observations: } 68 \text { after adjustments }\end{array}$} \\
\hline Variable & Coefficient & Std Error & t-Stati stic & Prob. \\
\hline$\underset{C}{\operatorname{ASII}(-1)}$ & $\begin{array}{r}-1.070451 \\
0.002175\end{array}$ & $\begin{array}{l}0.123293 \\
0.008211\end{array}$ & $\begin{array}{r}-8.682152 \\
0.264840\end{array}$ & $\begin{array}{l}0.0000 \\
0.7920\end{array}$ \\
\hline $\begin{array}{l}\text { R-squared } \\
\text { Adjusted R-squared } \\
\text { S.E. of regression } \\
\text { Sum squared resid } \\
\text { Log likelihood } \\
\text { F-statistic } \\
\text { Prob(F-statistic) }\end{array}$ & $\begin{array}{l}0.533172 \\
0.526099 \\
0.067653 \\
0.302079 \\
87.67567 \\
75.37976 \\
0.000000\end{array}$ & \multicolumn{2}{|c|}{$\begin{array}{l}\text { Mean dependent var } \\
\text { S.D. dependent var } \\
\text { Akaike info criterion } \\
\text { Schwarz criterion } \\
\text { Hannan-Quinn criter. } \\
\text { Durbin-Watson stat }\end{array}$} & $\begin{array}{r}-0.000699 \\
0.098275 \\
-2.519873 \\
-2.454593 \\
-2.494007 \\
1.983536\end{array}$ \\
\hline
\end{tabular}

Table 3:- Stationarity Test Results for AALI Stock Return

Source: Data Processed through EViewsApplication (2020) 


\begin{tabular}{llcccc}
\hline \multirow{2}{*}{ No } & \multirow{2}{*}{ Company Name } & \multicolumn{3}{c}{ In Level } \\
\cline { 3 - 6 } & & ADF & $\begin{array}{c}\text { Critical Values } \\
\mathbf{5 0 \%}\end{array}$ & Prob & Station erity \\
\hline 1 & PT. Astra International Tbk. & -8.682152 & -2.904848 & 0.0000 & Stationer \\
\hline 2 & PT. Astra Otoparts Tbk. & -7.614342 & -2.904848 & 0.0000 & Stationer \\
\hline 3 & PT. Goodyear Indonesia Tbk & -10.17691 & -2.904848 & 0.0001 & Stationer \\
\hline 4 & PT. Gajah Tunggal Tbk. & -6.792600 & -2.904848 & 0.0000 & Stationer \\
\hline 5 & PT. Indomobil Sukses Internasional Tbk. & -5.338333 & -2.904848 & 0.2020 & Stationer \\
\hline 6 & PT. Prima Alloy Steel Universal Tbk. & -8.713967 & -2.904848 & 0.0000 & Stationer \\
\hline
\end{tabular}

Table 4:- Summarized of ADF Test Results (In Level)

Source: yahoo.finance.com, Reprocessed Using the Views 9 Application

Based on Table 4, the results that obtained from ADF Test value were statistical stock return data the automotive sector stationary with ADF value < from Critical Value which is $5 \%$, so it needs to carry out further analysis

\section{Normality Test}

In this research, those normality test was carried out to determine whether the data return portfolio had normal distribution or not. Examination was done by comparing JarqueBera $(\mathrm{JB})$ with Chi Square X2 (a $=5 \%$, df $=2)$ of 5.99147.Here's the results of normality test for ASII stock return data could be seen in Figure 3.
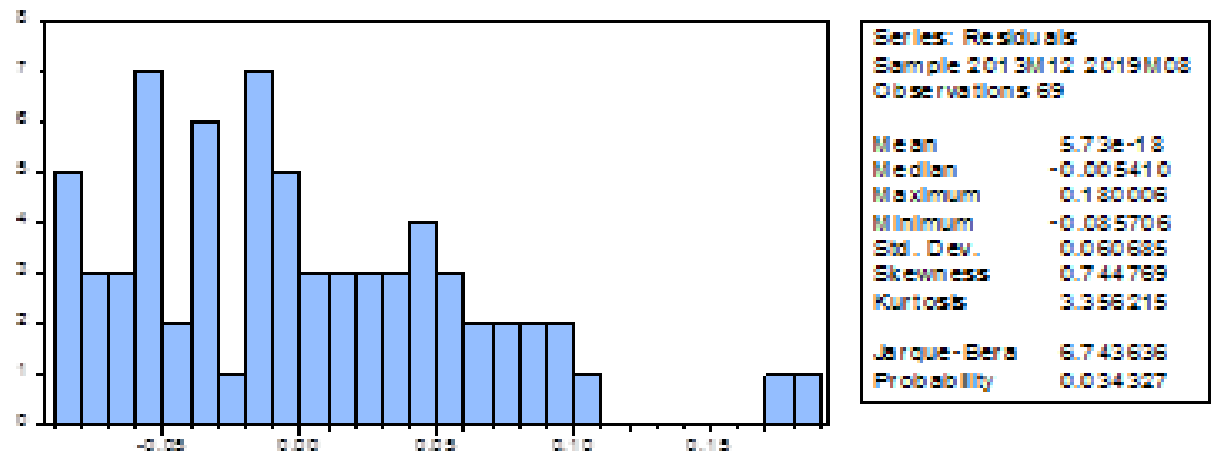

Fig.3:- Normality Test Results of PT. Astra International Tbk.(ASII) Source: data processed by EViews application (2020)

\begin{tabular}{|c|c|c|c|c|c|}
\hline No & Company Name & $\begin{array}{c}\text { Jorque- } \\
\text { Berra }\end{array}$ & Prob. & $\begin{array}{c}\text { Chi-Square (X2) } \\
\alpha=5 \%, \text { df }=2\end{array}$ & Normality \\
\hline 1 & PT. Astra International Tbk. & 6.743636 & 0.034327 & 5.99147 & Not Normal \\
\hline 2 & PT. Astra Otoparts Tbk. & 125.8493 & 0.000000 & 5.99147 & Not Normal \\
\hline 3 & PT. Goodyear Indonesia Tbk & 54.82603 & 0.000000 & 5.99147 & Not Normal \\
\hline 4 & PT. Gajah Tunggal Tbk & 66.27365 & 0.000000 & 5.99147 & Not Normal \\
\hline 5 & PT. Indomobil Sukses Internasional Tbk. & 36.59632 & 0.000000 & 5.99147 & Not Normal \\
\hline 6 & PT. Prima Alloy Steel Universal Tbk. & 61.48454 & 0.000000 & 5.99147 & Not Normal \\
\hline
\end{tabular}

Table 5:- Summary of Automotive Stock Return by Normality Test Results

Source: yahoo.finance.com that Reprocessed by Eviews Application (2019)

Based on calculation from Table 4.4 it said that test results from stock return data By Eviews 9 software, that all companies do not occurs normal distribution by comparison between the value of JarqueBera $>$ Chi Square X2 ( $a=5 \%$, df $=2$ ) of 5.99147.Innull hypothesis (H0) the return distribution was normal, if $\mathrm{JB}>\mathrm{X} 2$ then $\mathrm{H} 0$ was rejected, otherwise, if $\mathrm{JB}$ $<\mathrm{X} 2$ then $\mathrm{H} 0$ was accepted. The smaller the JarqueBera (JB )statistical probability value closure to 0 , then the residual hypothesis having a normal distribution Was rejected. If value
JarqueBera (JB) was less than value of Chi Square X2 $(\mathrm{a}=$ $5 \%$, df $=2$ ), which is, the value of $\mathrm{X} 2$ was equal to 5.99146, meaning that the data had normal distribution and the amount of skewness was zero, so you can immediately use a'. Results for JarqueBera (JB) ASII stock return data which obtained for 6.743636> X2 5.99147 means that ASII stock return data was greater than df 2 , so it could be concluded that stock retun data is not normally distributed. Then the value of a need to be corrected first by Cornish Fisher Expansion such as: 


\begin{tabular}{cclccc}
\hline No & \multirow{2}{*}{ Code } & \multicolumn{1}{c}{ Company Name } & $\begin{array}{c}\text { Skewness } \\
\text { Coefficient }\end{array}$ & $\mathbf{a ( 0 . 0 5 )}$ & $\boldsymbol{\alpha - 1 / 6}\left(\boldsymbol{\alpha}^{\mathbf{2}-\mathbf{1}) \boldsymbol{\xi}}\right.$ \\
\hline 1 & ASII & PT. Astra Intemational Tbk. & 0.744769 & 1.644853 & 1,433147274 \\
\hline 2 & AUTO & PT. Astra Otoparts Tbk. & 1.699342 & 1.644853 & 1,161803313 \\
\hline 3 & GDYR & PT. Goodyear Indonesia Tbk. & -1.527846 & 1.644853 & 2,079153766 \\
\hline 4 & GJTL & PT. Gajah Tunggal Tbk. & 1.225599 & 1.644853 & 1,296468029 \\
\hline 5 & IMAS & PT. Indomobil Sukses Intemasional Tbk. & -1.146557 & 1.644853 & 1,970769737 \\
\hline 6 & PRAS & PT. Prima Alloy Steel Universal Tbk. & -1.016033 & 1.644853 & 1,933557389 \\
\hline
\end{tabular}

Table 6:- Calculation Results of Cornish Fisher Expansion Return of Automotive shares

Source: yahoo.finance.com, Reprocessed by Eviews Application (2019)

Based on these table above, the a value for ASII stock return data after correction was amounted to 1.433147274. This number was smaller than value $a$, this $a$ number would be used for VaR return estimation to ASII shares.

\section{Heteroscedasticity Volatility Test with White}

Heteroscedasticity Test

Heteroscedasticity test aims to find out if this variance had constant returns or not. If these variance for this stock return was constant (homoscedastic) then the standard deviation could be calculated by the others standard deviation. And if from the test results obtained that the return of variant was heteroscedasticity or not constant, then the standard deviation cannot Calculated by statistical standard deviation equations but then should be calculated through ARCH/GARCH.

The white heteroscedasticity test was carried out by $\mathrm{E}$ views 9 software application, see the percentage of Probability F-statistic (p) for each stock return. If the probability value of F-statistic $<5 \%$, then the variance of return data was heteroscedasticity. Otherwise, if the value Probability Fstatistic> $5 \%$, then the variance of return data was homoscedasticity. Test result for White Test on stock return data was shown in Table 7.

Heteroskedasticity Test: White

\begin{tabular}{llll}
\hline \hline F-statistic & 51.15587 & Prob. F $(2,66)$ & 0.0000 \\
Obs*R-squared & 41.94306 & Prob. Chi-Square(2) & 0.0000 \\
Scaled explained SS & 46.59040 & Prob. Chi-Square(2) & 0.0000 \\
\hline
\end{tabular}

Table 7:- White Heteroscedasticity Test Results

Source: Data Processed by EViews Application (2020)

\begin{tabular}{cclccc}
\hline No & \multirow{2}{*}{ Code } & \multicolumn{1}{c}{ Company Name } & Prob & $\begin{array}{c}\text { Critical } \\
\text { Value }\end{array}$ & Test Result \\
\hline 1 & ASII & PT. Astra International Tbk & 0.0000 & 0.05 & Heteroskedasticity \\
\hline 2 & AUTO & PT. Astra Otoparts Tbk. & 0.0000 & 0.05 & Heteroskedasticity \\
\hline 3 & GDYR & PT. Goodyear Indonesia Tbk. & 0.0000 & 0.05 & Heteroskedasticity \\
\hline 4 & GJTL & PT. Gajah Tunggal Tbk & 0.0000 & 0.05 & Heteroskedasticity \\
\hline 5 & IMAS & PT. Indomobil Sukses Internasional Tbk. & 0.0000 & 0.05 & Heteroskedasticity \\
\hline 6 & PRAS & PT. Prima Alloy Steel Universal Tbk. & 0.0000 & 0.05 & Heteroskedasticity \\
\hline
\end{tabular}

Table 8:- Heteroscedasticity Test Results for Automotive White Return

Source: yahoo.finance.com, Reprocessed by EviewsApplication (2019)

Based on Table 8, the results from heteroscedasticity test would shows that all stock return data that the company produces a probability value $\alpha<5 \%$, it could be said that the sixth shares above had heteroscedasticity characteristics. Thus, the standard deviation could estimates of the stocks in automotive sub-sector were carried out by ARCH / GARCH model to overcome these heteroscedasticity in stock return data.
E. The Estimated Volatility of the ARCH / GARCH model to Automotive Stock Return

ARCH-GARCH estimation was Carried out to get the optimal model with chosen the model by the largest Log Likelihood value, Akaike info criterion (AIC) and Schwarz criterion (SIC)which smallest to selected the GARCH test with different type to discovered to the most appropriate model. The lower the AIC and SIC values, the more optimal model would obtained. These following table was the optimum model which presented in Table 9. 
ISSN No:-2456-2165

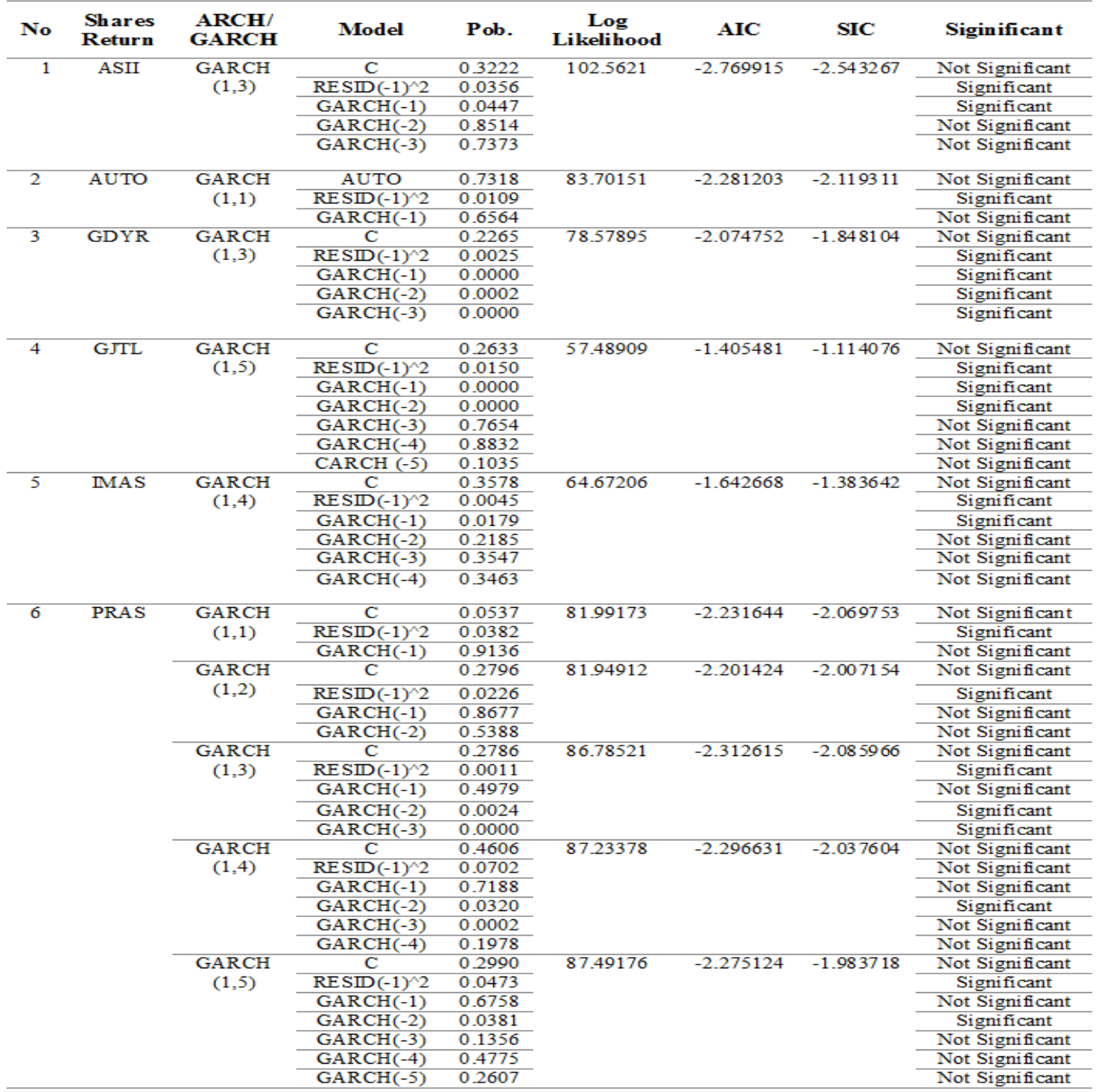

\section{Table 9:- Optimum Model Chosen}

Source: yahoo.finance.com and the Data was Processed by EViewsApplication

\section{F. Calculating VaR of Each Shares Return}

After these variance model was carried out, next the amount of each respectively Value at Risk return for automotive stocks. Value at Risk calculation was conduct by level of $95 \%$ confidence withholding period of 1 month, 3 months, 6 months. These following was an estimation result of Value at Risk for each Automotive stock and its component

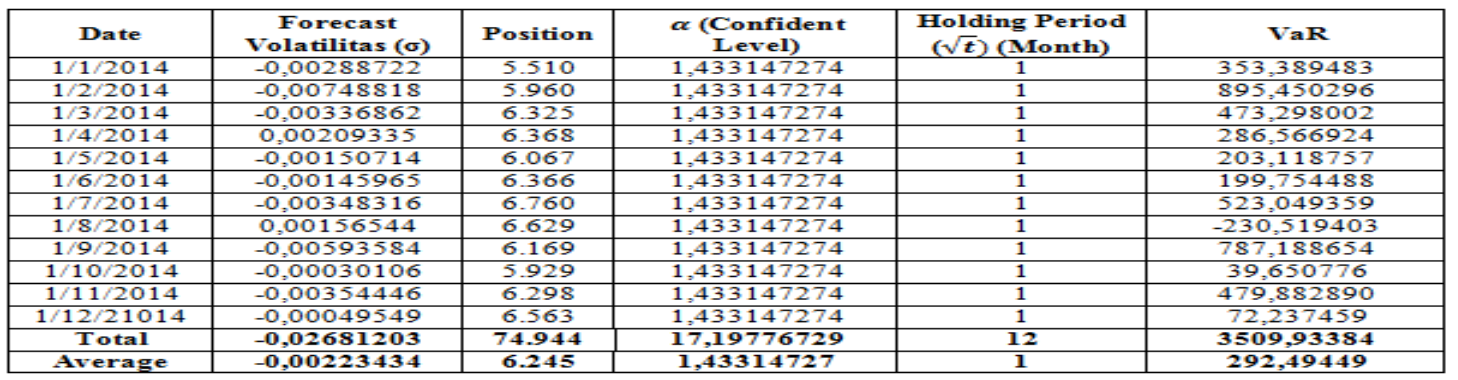

Table 10:- Calculation of VaR Monthly Return on ASII Shares throughthe GARCH model $(1,3)$ during Period of January 1,2014 to March 1, 2014

Source: yahoo.finance.com and the Data was Processed by Excel Application (2020) 
Based on table 4:12 with confidence level of $95 \%$ maximum potential lossthat occurred for a day on January 1, 2014 the calculation from volatility model of $\operatorname{GARCH}(1,3)$ when ASII share value position amounted of IDR 5,510 wasIDR353. In other words there had 5\% chance that the subsequent loss caused by position of ASII shares was IDR.5,510 with VAR value of IDR353. These following was summarized from the results of $\mathrm{VaR}$ estimation by ARCH/GARC Hmodels for period of 1 month, 3 months, 6 months:

\begin{tabular}{|c|c|c|c|c|c|c|}
\hline Return & Period & $\begin{array}{c}\text { Forecast } \\
\text { Volatilitas } \\
(\sigma)\end{array}$ & Position & $\begin{array}{c}\alpha \text { (Confident } \\
\text { Level) }\end{array}$ & $\begin{array}{l}\text { Hold ing } \\
\text { Period } \\
\text { (H? } \bar{?} \text { ) } \\
\text { (Day) }\end{array}$ & V aR \\
\hline \multicolumn{7}{|c|}{ Return ASII } \\
\hline $\begin{array}{l}\text { Total } \\
\text { Mean }\end{array}$ & 1 Month & $-0,00288722$ & 5.510 & 1,433147274 & 31 & 353,3894831 \\
\hline \multirow{2}{*}{$\begin{array}{l}\text { Total } \\
\text { Mean }\end{array}$} & \multirow[t]{2}{*}{3 Month } & $-0,01374402$ & 17.795 & 4,29944182 & 90 & 1722,13778108 \\
\hline & & $-0,00243624$ & 6.099 & 1,43314727 & 30 & 306,40735036 \\
\hline \multirow{2}{*}{$\begin{array}{l}\text { Total } \\
\text { Mean }\end{array}$} & \multirow[t]{2}{*}{6 Month } & $-0,01461746$ & 36.596 & 8,59888364 & 181 & 1838,44410217 \\
\hline & & $-0,00243624$ & 6.099 & 1,43314727 & 30 & 306,40735036 \\
\hline \multicolumn{7}{|c|}{ Return AUTO } \\
\hline $\begin{array}{l}\text { Total } \\
\text { Mean }\end{array}$ & 1 Month & $-0,00519180$ & 2,876 & 1,16180331 & 31 & 268,89095941 \\
\hline \multirow{2}{*}{$\begin{array}{l}\text { Mean } \\
\text { Total } \\
\text { Mean }\end{array}$} & \multirow[t]{2}{*}{3 Month } & $-0,01775640$ & 9.366 & 3,48540994 & 90 & 999,35275493 \\
\hline & & $-0,00591880$ & 3.122 & 1,16180331 & 30 & 333,11758498 \\
\hline \multirow{2}{*}{$\begin{array}{l}\text { Total } \\
\text { Mean }\end{array}$} & \multirow[t]{2}{*}{6 Month } & $-0,02128719$ & 19.343 & 6,97081988 & 181 & 1204,21726813 \\
\hline & & $-0,00354786$ & 3.224 & 1,16180331 & 30 & 6,58893611 \\
\hline \multicolumn{7}{|c|}{ Return GDYR } \\
\hline $\begin{array}{l}\text { Total } \\
\text { Mean }\end{array}$ & 1 Month & 0,00191865 & 1.306 & 2,079153766 & 31 & $-80,77963559$ \\
\hline \multirow{2}{*}{$\begin{array}{l}\text { Total } \\
\text { Mean }\end{array}$} & \multirow[t]{2}{*}{3 Month } & 0,03081076 & 15.755 & 24,94984519 & 365 & $-272,58748076$ \\
\hline & & 0,00256756 & 1.313 & 2,07915377 & 30 & $-90,86249359$ \\
\hline \multirow{2}{*}{$\begin{array}{l}\text { Total } \\
\text { Mean }\end{array}$} & \multirow[t]{2}{*}{6 Month } & 0,00676660 & 3.885 & 6,23746130 & 90 & $-570,96486399$ \\
\hline & & 0,00225553 & 1.295 & 2,07915377 & 30 & $-95,16081066$ \\
\hline \multicolumn{7}{|c|}{ Return GDYR } \\
\hline $\begin{array}{l}\text { Total } \\
\text { Mean }\end{array}$ & 1 Month & 0,00191865 & 1.306 & 2,079153766 & 31 & $-80,77963559$ \\
\hline \multirow{2}{*}{$\begin{array}{l}\text { Total } \\
\text { Mean }\end{array}$} & \multirow[t]{2}{*}{3 Month } & 0,03081076 & 15.755 & 24,94984519 & 365 & $-272,58748076$ \\
\hline & & 0,00256756 & 1.313 & 2,07915377 & 30 & $-90,86249359$ \\
\hline \multirow{2}{*}{$\begin{array}{l}\text { Total } \\
\text { Mean }\end{array}$} & \multirow[t]{2}{*}{6 Month } & 0,00676660 & 3.885 & 6,23746130 & 90 & $-570,96486399$ \\
\hline & & 0,00225553 & 1.295 & 2,07915377 & 30 & $-95,16081066$ \\
\hline \multicolumn{7}{|c|}{ Return GJTL } \\
\hline $\begin{array}{l}\text { Total } \\
\text { Mean }\end{array}$ & 1 Month & 0,01510853 & 690 & 1,296468 & 31 & $-209,4907477$ \\
\hline \multirow{2}{*}{$\begin{array}{l}\text { Total } \\
\text { Mean }\end{array}$} & \multirow[t]{2}{*}{3 Month } & 0,04037050 & 2.070 & 3,88940409 & 90 & $-541,57811552$ \\
\hline & & 0,01345683 & 690 & 1,29646803 & 30 & $-180,52603851$ \\
\hline \multirow{2}{*}{$\begin{array}{l}\text { Total } \\
\text { Mean }\end{array}$} & 6 Month & 0,06600267 & 4.285 & 7,77880817 & 181 & $-910,97577142$ \\
\hline & & 0,01100044 & 714 & 1,29646803 & 30 & $-151,82929524$ \\
\hline Return I & & & & & & \\
\hline $\begin{array}{l}\text { Total } \\
\text { Mean }\end{array}$ & 1 Month & $-0,02393883$ & 4789 & 1,9707697 & 31 & 3502,072185 \\
\hline Total & 3 Month & $-0,06874636$ & 14989 & 5,91230921 & 90 & 10165,51528499 \\
\hline Mean & & $-0,02291545$ & 4996 & 1,97076974 & 30 & 3388,50509500 \\
\hline Total & 6 Month & $-0,13829314$ & 29542 & 11,82461842 & 181 & 20251,28845969 \\
\hline Mean & & $-0,02304886$ & 4924 & 1,97076974 & 30 & 3375,21474328 \\
\hline Return $\mathrm{F}$ & & & & & & \\
\hline $\begin{array}{l}\text { Total } \\
\text { Mean }\end{array}$ & 1 Month & $-0,012207698$ & 177 & 1,93355739 & 31 & 64,7583537 \\
\hline Total & 3 Month & $-0,035342934$ & 560 & 5,800672167 & 90 & 192,604552340 \\
\hline Mean & & $-0,011780978$ & 187 & 1,933557389 & 30 & 64,201517447 \\
\hline Total & 6 Month & $-0,059864246$ & 1.193 & 11,601344334 & 181 & 341,732322267 \\
\hline Mean & & $-0,009977374$ & 199 & 1,933557389 & 30 & 56,955387044 \\
\hline
\end{tabular}

Table 11:-VaR Estimation Results through Volatility ARCH/GARCH model During Period of 1Month, 3 Month and 6 Month Source: yahoo.finance.com and Data Reprocessed by Excel (2020)

Based on Table 11, VaR calculation results for each automotive stock andcomponents, based on calculation from the optimum of ARCH / GARCH volatility model each shares of automotive had different levels of losses. Position of share value from PT Astra Otoparts Tbk.(ASII) on January 1, 2014 was IDR5,510 the possibility of potential occurrence with maximum loss of $5 \%$ in the next 1 month (31 days) was IDR353. Withapproach others in stock position IDR17,795 maximum loss value would be in the next 90 days is IDR1,722.In the stock position of IDR36,596 maximum loss 
value in the next 181 days is IDR1,838.According to Tandelil in (2010), the greater the risk, the greater the level fromexpected return. The amount of risk faced by investors from PT. Astra Internasional Tbk(ASII). Within period of 1 day, 1 month, 3 months and 6 months would experienced maximum loss which estimate about $5 \%$ from the funds that invested.

\section{CONCLUSION AND SUGGESTION}

\section{A. Conclusion}

\section{1) The ARCH-GARCH Optimum Model}

The results from the ARCH / GARCH optimum model return in automotive stock with the criteria of the largest log likelihood value, the smallest AIC and SIC value was ASII with the GARCH model (1,3), AUTO with GARCH model $(1,1)$, GDYR with GARCH model(1,3), GJTL with the GARCH model $(1,5)$, IMAS with the GARCH model $(1,4)$, and PRAS with the GARCH model $(1,5)$.

\section{2) Value at Risk Analysis Results for Automotive Shares and Components}

From these results of processed data through optimum model and analysis of Value at Risk that said there would be potential loss of 5\% at automotive and component stockson January 1, 2014 for 1 month including when ASII's share position of IDR5,510 with loss of IDR353. The position of AUTO's share value was IDR2,876 and would experience dloss of IDR268. The position of GDYR's share value was IDR1,306 and would experience loss of IDR-80,779. The position from share value of GJTL was IDR690would experience loss of IDR-209,490. The value position of IMAS shares amounted to IDR4,789 which have loss of IDR3,502.Share value position from PRAS was IDR177 with loss of IDR64.

\section{B. Suggestion}

\section{1) For Investors}

Before investing some funds, the investors needs to apply these Value at Risk (VaR) calculations first to estimate those risk in decision making. From the results of these research conducted, then It is advisable for investors to invest its money in automotive shares with holding period of 30 days because it has the smallest maximum risk (loss) level.

\section{2) For Further Research}

There are various kinds of volatility model approaches in calculating risk ARCH / GARCH models for example using E-GARCH, TGARCH, GJR-GARCH, or VaR portfolios through montecarlo in other industries are recommended to use risk calculations, for example volatility of banking shares, based on characteristics from existing data because the results from risk measurement with suitable volatility model approach would determine the risk value more accurate elyso it will be useful in making decisions when investing.

\section{REFRERENCES}

[1]. Asianto A., Siregar H. Mualana TNA. (2019). judulpenelitian"The Value At Risk Of Selling Option On Crude Oil West Texas Intermediate". School of Business, Bogor Agricultural University (IPB). Jurnal VaR of Sell Opt-WTI-Etikonomi Vol. 18-1.

[2]. Bilir, H. (2016). Value at Risk (VaR) Measurement on a Diversified Portfolio: Decomposition of Idiosyncratic Risk in a Pharmaceutical Industry. European Journal of Business and Management, 8 (6): 35-40.

[3]. Bodie, Z., A. Kane \& A.J. Marcus (2007). Investment. (7th Ed). New York: McGrow-Hill.

[4]. Bollerslev, T. (1986).Generalized autoregressive conditional heteroskedasticity. Journal Econometrica, 31:307-327.

[5]. Brigham, Eugene F., \& Houston, Joel F. (2011). Dasardasar Manajemen Keuangan (Terjemaahan). Edisi 10. Salemba Empat. Jakarta

[6]. Campbell, J., Lo, A. W. \& MacKinlay A.C. (1997). "The Econometrics of Financial Markets, Princeton University Press.

[7]. Dwipa, Nendra MursetyaSomasih. (2016) "Peramalan Value At Risk Menggunakan Metode Generalized Autoregressive Conditional Heteroscedastic(GARCH)" BuletinIlmiah Mat. Stat. dan Terapannya (Bimaster) Volume 05, No. 02 (2016), hal 267 - 276.

[8]. Engle RF. (1982).Autoregressive conditional heteroscedasticity with estimates of the variance of United Kingdom inflation. Econometrica. 50(4):9871008.

[9]. Fahmi, Irhan. Dan LaviantiHadi, Yovi. 2009. Teori Protofoliodan Analisis Investasi (teoridansoaljawab). Bandung : Alfabeta

[10]. Jorion P. (2011). Financial Risk Manager Handbook Plus Test Bank. Ed ke-6. New Jersey (US): John Wiley \& Sons. 44

[11]. Li et al. (2016). JudulPenelitian "The Price Determinants of West Texas Intermediate Crude Oil" Jakarta. JurnalMercuBuana University

[12]. Soedewi, Srie., PurqoAcep. (2015) 'Penelitian Analisis Volatilitas Lima SahamBerbedaSektorpadaIndeks Kompas100 denganMetode ARCH-GARCH”. JurnalProsiding SKF 2015

[13]. Waharika, IntanAway.,KomangDharmawan, Ni Made Asih, (2013). Judulpenelitian "Menaksir value at risk (var)

portofoliopadaindekssahamdenganmetodependugavolatil itasgarch". e-JurnalMatematika Vol. 2, No. 1, Januari 2013, 14-18. 